\title{
The Pioneer in the "Sound" World of Western Music: Japanese Military Band
}

\author{
Ziyun Lan
}

\author{
Guangzhou Foreign Language School, Guangzhou,511455, China
}

Corresponding Author's Email:2403576727@qq.com

\begin{abstract}
From the end of the Tokugawa period to the early Meiji Period, the governments had to open the door of Japan and carried out a series of reforms in response to both internal and external threats. To prevent colonization, the Shogunate decided to westernize its military system and establish military bands to transmit orders and improve morale. In the early Meiji Period, to accelerate modernization, the new Meiji government pushed the policy of "enriching the country and strengthening the military" and reformed national rituals based on the Western state ceremonies. The government organized military bands to perform Western music in national ceremonies and ushered in the large-scale dissemination of Western music in Japan. Throughout this process, military bands became the pioneer in the "sound" world of Western music and an important carrier of culture as they performed Western music across Japan.
\end{abstract}

Keywords: Western music, military bands, Japanese, the Shogunate, Meiji Period, military reform, drums and fifes, horn, ceremony.

\section{INTRODUCTION}

Early in the 16th century, as the world's maritime trade began to flourish, European merchant ships came and went via Japanese ports. Due to the arrival of Western sailors, therefore, the Japanese public's exposure to Western music occurred in a sporadic and unpredictable fashion. During this period, Western missionaries converted new Christians, introducing their culture via religious teaching. Thus, Japan first encountered Western music through Christian worship music specifically. Yet in 1588, the Japanese government issued a series of decrees in order to limit the spread of Christianity, immediately making Western music less accessible [1]. Any traces of Western music in Japan had soon almost disappeared.

The late Shogunate government imitated Western countries and carried out military reform in response to both internal and external threats. The Shogunate officials took inspiration from Western military bands to create their own, making Western music an intrinsic part of the military.

In the early Meiji Period, the new Meiji government believed that "strengthening the military" providing the "foundation for a rich country" [2]. The military reforms, based on the Western military system, led Japan to embark on the road of military modernization. Meiji officials also realized that military music was an integral part of Western governments and organized military bands to perform Western music in national ceremonies. In this way, the government ushered in the large-scale dissemination of Western music in Japan.

The establishment of Military Bands was not as a voluntary choice of the government but as a product of western-style military reforms. The spread of Western music in Japan, moreover, went hand in hand with the introduction of Western culture into Japanese society, leading to an almost immediate cultural exchange. Japanese people accepted, developed and transformed Western culture[3].

\section{THE ESTABLISHMENT OF MILITARY BANDS IN THE LATE SHOGUNATE}

Since the early 19 th century, foreign fleets had landed in Japanese ports frequently, prompting the Shogunate to pay closer attention to coastal defense. The outbreak of the Opium War deepened the Shogunate's sense of crisis as Japan faced the prospect of colonization [4]. In this context, the Shogunate, cowed by the military power of Western countries, decided to westernize its military system. Soldiers learnt Western drills and how to play Western military band instruments such as drums, fifes 
and signal horns in order to transmit orders and improve morale. Thus, military bands which played Western music became more and more important in the Japanese army and led to the large-scale spread of Western music.

\subsection{The Earliest Military Bands: Drums and Fifes Military Bands}

In Western armies, soldiers had used drums and fifes for centuries in marching songs to transmit orders and encourage fighting spirit on the battlefield. In Japan the earliest military bands also used drums and fifes, which originated from the Dutch drum. In 1855, the Shogunate not only bought warships from the Netherlands, but also commissioned teachers to conduct two Western-style drills and teach the Nagasaki navy the Dutch drum [5]. The Western drum, it is thought, was therefore taught in Japan for the first time in 1855. To establish military bands, the army recruited experienced drummers and later also introduced fifes to form drums and fifes military bands. These bands, made up of highly trained and musically talented soldiers, ultimately transformed into the Meiji naval band.

In 1863, violent protests against foreign trade and residents were common. In order to protect their citizens, therefore, both the British and French armies, alternately, stationed themselves in Yokohama [6]. Each had drums and fifes military bands and often performed with the Shogunate Army. After the Keio Period (1865-1868), with the military reform, many local governments set up military bands, playing music based on Dutch, French and British styles. In addition, a variety of music scores were published.

Besides demonstrating military exercises, these military bands played music at many events, such as parties, horse racing, dragon boat racing and concerts. Performances in residential areas meant this type of music, moreover, was accessible even to the general public. Its audience, therefore, expanded; it was now not only for army soldiers and government officials but also ordinary people. Consequently, more and more Japanese people came to appreciate Western music.

\subsection{The Developing Military Bands : Signal Horn Military Bands}

As brass instrument, the signal horn proved much more difficult to learn than the drum. The horn therefore, although introduced in the Keio Period (1865-1868), by the British army stationed in Yokohama, became popular more gradually. In 1867, the French military advisory group, composed of horn-players who served as sergeants in the infantry, came to Japan for the first time, and, in 1868, the Shogunate Army also formally adopted the French horn and began large-scale horn training, selecting 32 soldiers to teach[7]. From the second to third year of the Meiji Period (1869-1870), each army drill stations had a horn military band and horn instructors. The army used French signal horns, and the navy used English signal horns. It was not until the 18th year of the Meiji Period that the army and navy elected to use the same horn. At the end of the 1860s, horns replaced drums, as on the European continent, since gunfire drowned out the sound of drums in modern wars. First used for practical purposes, drums and fifes soon became decorative elements.

\section{THE EXPAND OF MILITARY BANDS IN THE MEIJI PERIOD}

At the end of the Shogunate Period, due to military reform, Western style-drills encouraged the transmission of Western music, which was used to issue instructions and boost morale. In the Meiji Period, however, the purpose of Western music, as well as how it was performed, altered significantly. Whereas previously military bands played drums and fifes to march and drill, in the Keio Period (1865-1868), they were mainly used in ceremonial activities.

\subsection{Fenton, the First Military Music Teacher}

When it comes to discussing the history of military bands, Fenton's name inevitably was mentioned. His full name was John William Fenton and he is the first Japanese military band teacher. Fenton was reportedly born in Cork in the Irish Republic in 1828. He joined the British Army at the age of 13, served as a drummer until his rise to sergeant in 1854 and was appointed the captain of the First Battalion of the 10th Company's Marching Band in 1864. He was transferred from the colonies to Yokohama following his unit in 1868. In 1872, Fenton graduated from the British Army Military Academy, becoming a captain. Given that he had served as captain of a mature British military band and also attended a regular military school, Fenton was the perfect choice for instructor of the new Japanese military band[8].

In the second year of the Meiji Period (1869), when Fenton served as the commander of the 10th Company, he signed a contract with the Satsuma Band. As Fenton had performed well instructing the old Satsuma students and the Ministry of War also modelled itself on the British military system, Fenton was once again hired as a military music teacher. In the same year, Fenton's regiment, the First Battalion of the 10th Company, was transferred to other strait colonies, but Fenton chose to retire in Yokohama in order to remain in Japan as a music teacher.

In the tenth year of Meiji Period, Fenton's contract expired and the navy eventually decided to dismiss Fenton.

In the eight years that Fenton was a music teacher in Japan, he participated in and witnessed the establishment and development of the Military Band of the early Meiji 
Period. This period saw the beginning of the professional and large-scale dissemination of Western music in Japan. Overall, Fenton played an extremely important role in the growth of the military band in Japan, whether with the music theory books he used, the music scores he bought or the pieces he performed. More significantly, Fenton instructed a whole generation of musicians who knew Western music intimately, profoundly impacting the subsequent development of music education and even composition in Japan, which was often also influenced by Western music.

\subsection{The Satsuma Military Band: the Foundation of Military Bands}

During the Anglo-Satsuma War in 1863, the Shogunate army heard the music played on British warships and witnessed first-hand the remarkable effect it had on soldiers. Some scholars argue that it was at this point that the Satsuma band to begin to teach music to its troops. In 1867, the Satsuma, in order to fully anglicize the military system, set up a British-style military band with drum, fife and horn players. More than 30 Satsuma soldiers were selected to learn under Fenton from the British infantry in Yokohama. The students first learnt signal horn, then how to read music, and then the fife, drum and horn and other musical instruments, following the Western model. From July 1870, students also began to learn how to play wind instruments when those bought by Fenton from London arrived in Japan[9]. Wind music was only performed for approximately three months as part of military drills, during which the repertoire consisted of Kimigayo, English Marching Score, Slow Marching Score and only four or five other pieces. In the third year of Meiji Period, the band members were ordered to return to their previous stations. In the fourth year of the, however, the official decision was made to set up royal troops and, in response, the Satsuma Military Band were sent to the capital again that April.

When the naval marching band was first established, most of the members were recruited from Kagoshima. The navy could not only draw on the experiences of the players from the Satsuma band who had been trained in the British style, but the military music students who returned to their respective stations in September had become highly skilled in playing Western music by the third year of the Meiji Period (1870). For these reasons, recruiting members from the Kagoshima was seen as the most effective way to create the naval marching band. In the first decade of the Meiji Period, the navy band performed at the majority of official and court events, since the army military band was only trained in French signal horn. It can be argued, therefore, that the Satsuma band had a huge impact on the development of both the army and navy bands and the foundation of military bands.

\subsection{Separation of Army and Navy Military Bands in the Fourth Year of Meiji Period}

In the fourth year of the Meiji Period, with the acceleration of military reform and frequent changes occurring within the military establishment, the army and navy marching bands also underwent rapid transformation. A symbol of its growing power, the Meiji regime successfully established the Japanese army in the same year. Both the Imperial Army and the Navy received funding to establish their own military bands which would specialize in Western music" [10].

According to the records of Fifty Years of Music, the Ministry of War established the Military Band, with the Satsuma Military Band at the center. In August of the Meiji Period's fourth year (1871), the Ministry of War was abolished and the Ministry of the Army and the Ministry of the Navy separated. The British-style naval military band at this point had already begun to flourish, whereas the French-style army band developed only a year.

The military band began to develop properly during the fourth year of the Meiji Period. The government recruited new members over the following years on four separate occasions. In the ninth year of Meiji Period, with the abolishment of the naval corps the drum corps also came to an abrupt end. A drum player who wished to become a professional player faced new difficulties, as he could only transfer to civilian work or apply to be released from the military. During this period, the horn replaced drum as signal. The naval band meanwhile became independent, a military music section which was subsumed under the jurisdiction of the military service bureau. Most of the early members were scholars. As a result of a reform that took place in the ninth year of the Meiji Period, all the band's members, from deputy officers to students, became corporals.

\subsection{The Navy Band in the Tenth Year of the Meiji Period: Stable and Mature}

In the early Meiji Period, before the popularity of Western music was at its height, recruitment for military bands was based on age, physical fitness and literacy, rather than musical potential. Later, however, around the tenth year of the Meiji Period, officials adopted a new system, the military music non-resident student system[11]. It was referred to, after six months of study, members were tested to determine whether they had the necessary musical aptitude to become military band members. Those who passed continued with their training. Students who failed the exam the first time had a second opportunity to take the exam two months later. From then on, the marching band selected non-resident student applicants according to the number needed each year, making significant improvements to both the methods of recruitment and training. Evidently, the planning, 
recruitment and training methods for military band members were becoming more standardized and systematic; This demonstrates that the government at that time saw the success of the military band as extremely important and believed Western music was better able to maintain military discipline and morale, and also edify and educate the people, than any other type of music.

In the tenth year of the Meiji Period, after Fenton had left Japan, opportunities to play music began to crop up more frequently. The government chose German military music teacher Franz Eckert as the instructor of the naval military band, which looked to be entering a new era of music. In the eleventh year, the naval marching band purchased a piano. Eckert instructed the naval marching band to learn "the fundamentals of music and melody" through the piano and how to play the piano, military band members were better able to hone their sense of sound and grasp the structure of music[12]. Composing and arranging music also became more likely. At that time, the Naval Ministry agreed that these two skills were also becoming more important. Later, the introduction of instruction in the piano, therefore, not only led to music becoming more accessible and widespread, but also to military band members who were skilled in composition, as well as musical pieces which were unique in both style and subject matter. The Japanese had ushered in the second stage of teaching Western music, with integrated learning as the goal, and they would continuously devote themselves to improving the "quality" of music playing and studying the technology of musical composition and arrangement.

\section{PERFORMANCES OF MILITARY BANDS IN THE EARLY MEIJI PERIOD}

In order to modernize, the new Meiji government constantly drew on what it saw as an advanced civilization, as enjoyed by the Western powers, and began to reform various systems. This included reforming the state rituals. Ranging from imperial tours, in which the emperor was lionized as the head of state, to diplomatic ceremonies and epochal ceremonies in which the opening of new businesses was celebrated. Early in the Meiji Period, Japanese diplomats who were sent to European courts noticed that military music was an important part of the Western "ceremonial way of running the country" [13]. The Meiji government, therefore, allocated funds to the army to set up the military bands and used them in these ceremonies to play Western music, which injected color into each ceremony with its unique musical style and allowed Western music to reach a wider audience.

\subsection{Mikado's Patrol}

Mikado Meiji, as the leader of the new era, frequently demonstrated his power and charm to his audience through elaborate performance. The two patrols in the first year of Meiji Period, planned by the Meiji government, for instance, were of a strong political nature.
When these patrols travelled, they were accompanied by a military band of drums and fifes. As the army developed, military bands played Western musical instruments on a larger scale, particularly during regular military parades and training ceremonies in the presence of the Mikado. When the Mikado toured, for example, military bands played loud music to make people aware of the Mikado's presence. These military ceremonies reflected and reinforced Mikado's role as the country's top military commander. The Mikado's ceremonial music, Kimigayo, the first piece of Western music composed by Fenton, functioned similarly to the Western Royal Salute, was played by the military band frequently.

Both the Mikado's ceremonial practices and music were modelled on Western practices. Cutting a striking presence on both a visual and auditory level, he left a deep impression on those around him. In contrast, in the Edo Period, when the general of the Tokugawa Shogunate went out, others were not allowed to look at the general and the soldiers on the field had to remain quiet out of respect for the majesty of the general. In other words, with the Meiji Restoration, the "silent, solemn ceremony" transformed into a "lively, grand ceremony". Instead of emphasizing a respect for authority by encouraging silence, the audience were taught to associate power with accompanying music. It therefore became a symbol of the new era's arrival.

\subsection{Diplomatic Activities}

In addition to accompanying the Mikado's travels, military bands played Western music on diplomatic occasions where Western etiquette was called for. After the Meiji Restoration, the new Meiji government was forced to open the country, rather than pursue the Shogunate's policy of isolationism. It therefore actively adopted the Western style of etiquette on diplomatic occasions[14]. State guest receptions in the second, fifth and sixth years of the Meiji Period provided an excellent opportunity for the new Meiji government to learn about and emulate Western etiquette first hand. During the Russian prince's visit in the fifth year of the Meiji Period, the influence of Western customs on the Japanese government was already clear. There was a welcome ceremony, a visit from the Mikado and Empress, a joint military parade and a reception banquet, whilst the Navy Military Band had performed the national anthem of both countries. In the sixth year of the Meiji Period, moreover, at another reception, Western music was played at a luncheon party held by the Mikado at the imperial palace. After that, not only were Western-style feasts customary at reception ceremonies, but other kinds of banquets held in the palace had also become common. 


\subsection{Court Ceremony}

After the Meiji Restoration, the Meiji palace once again became the center of Japanese ceremonial activities at home and abroad. Meanwhile, the government changed and abolished all kinds of old palace habits. At the celebration banquet held for the Emperor's birthday, a military band now played Western music. After the fourth year of the Meiji Period, all banquets, whether for fiestas, military parades, welcoming officials and envoys from various countries, were held in the palace, including on the Emperor's birthday. At the banquet held in the sixth year of the Meiji Period, Western cuisine and music replaced traditional Japanese cuisine and music. Following this, the Western banquets were also served when there was a dinner party in the palace. In order to adapt to such occasions, at the end of the seventh year of the Meiji Period, the court ordered all the musicians who had previously been responsible for playing Japanese traditional music at the court to study Western music as well. In the 11th year of Meiji Period, the performance of Western music on the Emperor's birthday was formalized, together with dance music at the New Year banquet and kume mai at the Epoch Festival banquet.

\subsection{New Ceremonies}

Whether they were to celebrate the opening of a business or school, graduation, or an exhibition, all these new ceremonies fit into the category of the "lively, grand ceremony" which was rarely seen before the Meiji Period. The opening of the railway in the Meiji Period's Fifth Year appears to be the beginning of the trend, but these ceremonies became more popular in the tenth year of the Meiji Period. The influence of Western music increased with its performance at these ceremonies, more so than at the events celebrating the Emperor. Because the audience for these new ceremonies was not only larger but drawn from different social strata, but the audience on government ceremonies was very small, made up of military and government personnel. In addition to music performed for the ceremony itself, Western music was also played for recreation at these events similar to concerts for a large audience.

In response to the increasing demand from the private sector, for example, former members of the military band formed the Downtown Music Band. Moreover, people drew inspiration from Japanese concerts to hold regular concerts at which Western music was played. Additionally, charity concerts, held by various groups, were also popular in this period. In the twentieth year of the Meiji Period, there was a real and new wave of change in in society relating to Western music. Western music, previously played only on "closed occasions" at particular ceremonies, became popular on "open occasions", such as at concerts, which were more accessible to the general public[15]. As more and more people came to appreciate Western music, individuals as well as groups, such as the military band, became interested in playing it as a recreational activity.

\section{CONCLUSION}

In the late 19th century, the world was changing rapidly. European powers, such as Britain and the United States, forced the Japanese government to open the country for trade. Since the Edo Tokugawa period (16001868), the Japanese central government had adopted a closed foreign policy which secluded Japan from the outside world. At the end of the Tokugawa period, however, the government implemented a series of reforms in an attempt to modernize Japan. One of the most important reforms that took place during this period was the Shogunate's military reform, which led to the adoption of Western military technology. Western countries not only had a huge influence on the Japanese military in terms of technology, but also music. The drum and fife and signal horn marching bands came into being due to such military reforms. The military band developed quickly, enabling Western music to spread on a large scale. The role of Japanese military bands and the promotion of Western music also had a wider influence on the general public, representing how Western culture more broadly became popular in Japan.

In 1868, the Meiji Restoration ushered in an upheaval of Japanese society. The new Meiji government reformed national ceremonies and rituals in imitation of Western countries in order to accelerate modernization. The Japanese government paid more and more attention to the development of military bands and encouraged the Education Department to set up music classes in schools so that military bands would have a pool of musically educated students to recruit members from. The military band also, therefore, played an indispensable role in the musical education of Japanese people.

The rapid development of Japanese military bands in just over 20 years benefited the Japanese army as it unified the national army and boosted morale. At the same time, military bands played a great role in Japan's political and economic relationships with Western countries as they took center stage at diplomatic events as evidence of Japan's civilized status. Japanese citizen were also exposed to music with obvious Western characteristics, as military bands popularity and their reach increased, demonstrating that Western culture more widely was well received and appreciated in Japan.

History is always advancing. The Japanese entered the "sound" world of Western music and began to be influenced by it. With the opening of the country's door, Japanese people opened their own culture to change, responding with creativity to Western culture, laying the foundation for the development of strong localized culture later. 


\section{REFERENCES}

[1] Wade, C. Bonnie（2005） Music in Japanese, Oxford University Press, Oxford

[2] Wang. Xinsheng (2005) A Brief History of Japan, Peking University Press, Beijing

[3] Ye. Weiqu, Tang. Yuemei, (2007) History of Japanese Culture, Kunlun Press, Beijing

[4] Cukahara. Yasuko, (1992) Japan's Acceptance of Western Music in the 19th Century, Musicology, 37: $12-59$

[5] L. Fei, (2009) Japan's Acceptance of Western Music in the 19th Century Translation with a Book Review, Journal of Shanghai Conservatory of Music, 49: $81-82$

[6] Tian Zhongzhang, (2000) History of Japan, Xinxing Press, Beijing

[7] Malm, William P ,(1959) Japanese Musical and Musical Instruments, Tokyo and Rutland, Vermont: C.E. Tuttle

[8] Iba, Takashi (1982) History of Japanese Music. Translated by Lang Ying. Beijing: People's Music Press

[9] Seiyo Gunka Shushukan, A Collection of Western Military Music, http://gunka.sakura.ne.jp/en/tekihaikuman.htm

[10] Schneider, Eta Harich,(1973) A History of Japanese Music, London: Oxford University Press

[11] Jansen, Marius. B. eds,(1989) The Cambridge History of Japan, Vol. 5: The Nineteenth Century. Cambridge: Cambridge University Press

[12] Nettle, Bruno, The Western Impact on World Music: Change, Adaptation, and Survival, N.Y.: Schirmer Books, 1985

[13] Chou, Wen Chung, "East and West, Old and New", Asian Music1:19-22, 1968-1969

[14] Kaigo, Tokiomi, "The American Influence on the Education in Japan", Journal of Educational Sociology 26(1): 9-15,1952

[15] Wade, Bonnie (2014) Composing Japanese Musial Modernity. Chicago: University of Chicago Press 